\title{
Guidelines for Author
}

Artikel yang diterbitkan di Jurnal Civics: Media Kajian Kewarganegaraan adalah:

1. Artikel sesuai dengan focus and scope Jurnal Civics: Media Kajian Kewarganegaraan, belum pernah terbit dan tidak sedang proses di tempat lain.

2. Artikel tidak mengandung unsur plagiarisme lebih dari $30 \%$

3. Artikel ditulis dengan menggunakan bahasa Indonesia yang baik, gunakan alat bantu seperti grammarly (untuk bahasa inggris) dan typoonlie (untuk bahasa indonesia) agar mengurangi risiko kesalahan penulisan.

4. Artikel minimal terdiri dari 6 halaman dan tidak lebih dari 12 halaman.

5. Gunakan aplikasi seperti Mendeley, Zotero atau EndNote untuk keperluan reference management and formatting dengan style APA

6. Pastikan nama-nama yang tercantum dalam artikel benar-benar memiliki peran dalam penulisan artikel

7. Pastikan nama penulis dalam artikel dengan yang tertera dalam OJS sama (jika memiliki akun google scholar dan ORCID disarankan untuk mengisikannya pada bagian meta data penulis di OJS)

8. Untuk memudahkan dalam menyiapkan artikel, gunakan template yang telah disediakan Jurnal Civics: Media Kajian Kewarganegaraan.

a. Lakukan copy paste text only, kemudian pilih style yang telah disediakan pada bagian ribbon style

b. Simpan artikel Anda dalam format ".doc"

9. Tuliskan judul artikel Anda:

a. Tidak lebih dari 18 kata dan tidak menunjukkan dampak yang sempit

b. Hindari menggunakan kata study kasus, pengaruh

10. Penulisan afiliasi menggunakan format: Prodi, Universitas, Kota, Negara

11. Dimohon mencantumkan email seluruh penulis.

12. Abstrak tidak 150 - 200 kata, tidak mengandung unsur sitasi.

13. Sistematika sesuai dengan template yang telah digunakan Jurnal Civics: Media Kajian Kewarganegaraan.

14. Sitasi, penulis tidak dibenarkan melakukan sitasi dengan cara menyalin dari publikasi lain yang belum dibaca sumber aslinya. Misal Axxxx dalam Bxxxx

15. Referensi yang digunakan minimal 10, dengan minimal $70 \%$ dari sumber primer, sangat dianjurkan untuk menggunakan 10 tahun terakhir. 
Nilai budaya lokal Kee'rja Banyau sebagai pembentukan karakter kebangsaan Fusnika dan Debora Korining Tyas

Analisis nilai-nilai dalam Undang-Undang Simbur pada masyarakat Ogan Ilir

Asmaul Husna, Alfiandra Alfiandra, dan Sri Artati Waluyati....

Teachers and technology: The perspective of digital citizenship

Rini Triastuti.....

Pendidikan kewarganegaraan sebagai wahana untuk meningkatkan kesadaran hidup yang lebih baik bagi sesama

Juliati Juliati, Wawan Hermawan, dan Mohamad Firman

Dari terminologi ke subtansi pendidikan kewarganegaraan: Implikasi terhadap revitalisasi Pancasila

Freddy K Kalidjernih dan Winarno.....

Pemberdayaan penyandang disabilitas pada objek wisata Kuta Bali

Dermawan Waruwu dan Ni Ketut Jeni Adhi.

Analisis kebutuhan perancangan aktivitas pembelajaran berdasarkan pada dimensi sikap moral bagi siswa sekolah dasar

Auliya Aenul Hayati, Dina Pratiwi DS, dan Ena Suhena Praja.

Pembinaan karakter anak pada masyarakat perumahan di pinggiran kota Muhamad Abdul Roziq Asrori

Pengaruh model kooperatif tipe think pair share terhadap kerjasama siswa Khikmah Fitriani Nurazizah dan Wuri Wuryandani

Pancasila dan toleransi pada tradisi keagamaan masyarakat Yogyakarta Nurainun Mangunsong dan Vita Fitria

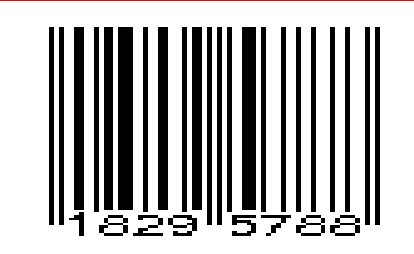

